\title{
DIFFICULTIES FACED BY THE STUDENTS IN ANSWERING TOEFL TEST QUESTIONS
}

\author{
Nurfitriyah Halim \\ STKIP YPUP Makassar \\ fitrihalim85@gmail.com \\ Sri Yulianti Ardiningtyas \\ STKIP YPUP Makassar \\ yyoubee@gmail.com
}

\begin{abstract}
This research was aimed at identifying the difficulties in answering TOEFL test questions. This research applied a focused description as the method of collecting the data and was located within a qualitative research paradigm. The population of the research was the seventh-semester students of English Department of STKIP YPUP who have undertaken TOEFL test for any purposes, and the sample of this research was chosen by using homogenous sampling. The sample consisted of 30 students. The data is collected using an open-ended questionnaire. The order of data collecting was listing the target population, selecting the sample subject, distributing a questionnaire and collecting the questionnaire. Concerning this research, it was focused in finding out the difficulties faced by the students in answering TOEFL test questions. The difficulties are personal trait based on their experience. This research was restricted to the difficulties in answering TOEFL test of English department students at the seventh-semester in STKIP YPUP Makassar who have undertaken TOEFL test for any purposes before. The findings of this research was the difficulties faced by the students in answering the TOEFL test questions, they were, fewer basic skills, less practice, less motivation, and students' individual differences.
\end{abstract}

Key words: Difficulties, TOEFL

\section{A. INTRODUCTION}

he correlational studies on language testing, language teaching, and language
acquisition were developed rapidly. Upshur (1971) had observed that these three
disciplines had an intrinsic mutual relationship where language testing both serves and

is served by research in language acquisition and language teaching. Furthermore, he pointed out that language test is one of criterion that mostly used to measure language abilities in second language acquisition research.

Parallel to this, language test is believed to be able to be valuable sources of information about the effectiveness of learning and teaching. (Brown 2003; Bachman 1995 in Hussain 2015) A test is a method of measuring a person's ability, knowledge, or performance in a given domain. Desheng and Vergese (2013) indicated that test evaluates not only the progress and achievement of learners but also the effectiveness of the teaching materials and methods used.

English proficiency test in a country where English as a foreign language is necessary as a valid test to measure one's English capability. English proficiency test is taken not only in 
attempting to pursuing study abroad but also as a requirement to complete college, especially in institutions. TOEFL (Test of English as Foreign Language) is the most popular test used in many countries in all over the world. Clark (2014) stated that according to ETS (Educational Testing Service), the TOEFL test is used by more than 9.000 colleges, universities and agencies in more than 130 countries to help them make admissions decisions, making it the most widely accepted English-language test in the world. A reported 27 million people had taken the TOEFL test in the world.

In Indonesia, especially in Makassar, the TOEFL test is as one of the requirements for students who want to continue their study into a higher level. It is also considered to be a stipulation applying for a job. Moreover, almost all institution requires a TOEFL test score test if a student wants to finish their study especially those in the English department. STKIP-YPUP is one of the institutions which obligates the students to take TOEFL test and meet the standard score as the requirements to finish their study. Since the test is measuring students' English proficiency which covered many skills like listening, reading, grammar, writing, vocabulary and error analysis, it is considered difficult for many students. As the result, many students failed the test; their score did not meet the standard even the local standard which determined by the institution. English Development Program (EDP) of STKIP-YPUP claimed that in the year of 2016 about 35 \% of students failed. Seeing that they are from the English department, this is considered as a problem that needs to be solved. All these lead the researchers to research in this particular area; that is, difficulties faced by the students in answering TOEFL test questions.

\section{B. REVIEW OF LITERATURE}

\section{Previous of related findings}

Regarding the importance of discovering the difficulties faced by the test takers in answering TOEFL test questions, the various study has been conducted to explore the case.

Mahmud (2014) found that that the main problems of the students in answering the TOEFL test were due to several conflicting reasons, such as fewer basic skills, less practice, less motivation, and students individual differences such as age and social-status.

Halim (2008) explored that Generally, the students encountered difficulties in answering TOEFL questions and it is because of bias. Cultural bias in TOEFL questions can be found mostly in the oral mode of the questions and some parts of the reading section. The element of culture in the language used in TOEFL questions that contain bias are conversational implicatures, idiomatic expression, metaphors, proverbs, slang, some registers and problems with deixis (to some extent). 
Hardin (2014) concluded that time management, missing keywords, unfamiliar vocabulary and getting caught up in details are common TOEFL reading difficulties.

Al-Rawashdeh (2010) concluded that there are real difficulties face graduate students during their preparation for the TOEFL test, and the most important of it was that related to students themselves as course and test tuition fees. The researcher recommends that each university should work with the High Ministry of Education to overcome these difficulties so that they do not hindrance students' preparation for the TOEFL test.

From some previous related studies above, it can be inferred that TOEFL test questions still become problems for students in English foreign language area. Various difficulties faced by the students in answering TOEFL test questions prove that there are many difficulties found. It does not rule out the possibility that there are still many problems that caused students to feel difficult in answering the TOEFL test.

\section{Some pertinent ideas}

\section{a. Difficulties}

According to Merriam Webster online dictionary, difficulty is the quality of something that makes it hard to do or the difficult nature of something. If we want to relate it with the English proficiency test, it is a quality of something that cause the test takers are hard to gain the score they want. There many obstacles that prevent them from getting qualified results in the test.

The TOEFL test is probably one of the most often used examination in the admissions process of foreign students to colleges and universities in the United States and other countries, including Indonesia. Besides, it is also used in the admissions process of applicants to get a job in companies where English is used to communicate with their joint companies abroad. Nevertheless, the test takers are still found it hard to fulfill that admissions process. Mahmud (2014) found problems in testing, they are:

\section{1) Fewer basic Skills}

The main problems in answering English proficiency test is that the test takers have no basic skills in English. Respondents demonstrated low capabilities in understanding English grammar. Indeed, the materials should be started from the very basic level such as a subject pronoun, object pronoun, verb forms, etc. The problems existed since, in the TOEFL materials, the students were expected to know more about more complicated problems such as subject and verb agreements, parallel structures, etc.

Therefore, teachers sometimes spent a lot of time explaining very basic grammar and did not have more time to practice for other sections in the TOEFL test. 


\section{2) Less Practice}

Mahmud (2014) claimed that however the students were given the course as preparation before joining the test, as a matter of fact, many of them did not commit their time to the course. Even when they had taken the course, students showed fewer struggles. Consequently, less practice was experienced during the course.

\section{3) Less motivation}

Several students undertook such test only for the certificate. However the motivation to pursuing study abroad can be the best trigger for them in gaining a good score in TOEFL, they still cannot afford to prove it. Therefore, less motivation is one of the problems hindering the students to get a good score in the proficiency test, in this case, is the TOEFL test.

\section{4) Students' individual differences}

Students' individual differences such as age and social status contribute to the learning process and made problem in their test.

\section{b. Description of the TOEFL Exams}

The Test of English as a Foreign Language (TOEFL) is an examination used to evaluate a nonnative English speaker's proficiency in the English language. Many North American colleges or Universities, as well as a large number of institutions, agencies, ask for official TOEFL score reports. An acceptable score on the TOEFL depends on the specific requirements of the particular institution or agency involved. The format of TOEFL test can be seen in the following table:

Table 2.1. TOEFL format of ITP

\begin{tabular}{|c|c|c|}
\hline Section & $\begin{array}{c}\text { Number of } \\
\text { Items }\end{array}$ & Time \\
\hline \multicolumn{3}{|l|}{ Listening Comprehension } \\
\hline Part A similar statement identification & 20 & \\
\hline Part B questions over short conversations & 15 & \\
\hline Part C questions over mini-talks & 15 & \\
\hline Total & 50 & $30-40$ minutes \\
\hline \multicolumn{3}{|l|}{ Structure and Written Expression } \\
\hline Identifying correct completion & 15 & \\
\hline Identifying incorrect words or phrases & 25 & \\
\hline Total & 40 & 25 minutes \\
\hline \multicolumn{3}{|l|}{ Vocabulary and Reading Comprehension } \\
\hline Identify synonyms & 30 & \\
\hline Reading passages & 30 & \\
\hline Total & 60 & 45 minutes \\
\hline \multicolumn{3}{|l|}{ Test of Written English (TWE)* } \\
\hline One essay, $250-300$ words & 1 & 30 minutes \\
\hline
\end{tabular}

*The Test of Written English is given five times a year. 
Volume 4, Number 2, December 2018

Listening comprehension aims to demonstrate the ability to understand spoken English. Examinees must listen to a tape and respond to various types of questions. Structure and written expression are to demonstrate the ability to recognize grammatically correct English, and examinees must choose the correct way to complete sentences and must find errors in sentences. Vocabulary and Reading comprehension is used to demonstrate the ability to understand written English, examinees must answer questions about the meanings of words and ideas in the reading passages. In the test of written English, examinees must write an essay on a given topic in thirty minutes to demonstrate their ability to produce correct and meaningful English.

The scoring system in TOEFL test is not the percentage of correct answers. Statistical procedures are used to convert the correct-answer score into a score that equates the scores for people of equal ability. In other words, if a particular test is more difficult, the converted score would reflects the same English ability that the taker's score on an accessible version would reflect.

\section{RESEARCH METHOD}

This research used a descriptive method. Before collecting the data, the researcher was assumed to have a category of the data that are needed for the research purposes. Since the goal of this research was to describe, explain, and explore issues associated with difficulties in answering TOEFL test questions by the seventh-semester students of English department at STKIP YPUP Makassar, this research was located within a qualitative research paradigm and was descriptive and explanatory.

\section{Respondents}

The population of this research was the seventh-semester students of English Department at STKIP YPUP Makassar in the academic year of 2017/2018 which consist of 100 students. Since the sampling technique used is purposive technique, the researchers chose 30 students who have undertaken the TOEFL test before as the sample.

\section{Instruments}

In conducting the research, the researcher uses an open-ended questionnaire. The questionnaire is used to cast their difficulties in answering TOEFL test questions.

\section{Procedures}

The order of the data collecting was in the following steps:

1. Listing the target population of the research;

2. Selecting the sample subject who met the requirements (the seventh semester students of English Department at STKIP YPUP Makassar in the academic year of 2017/2018 ); 
3. Distributing a questionnaire to the sample;

4. Collecting the survey from the sample participants;

\section{Data analysis}

This research applied an after-data-collection analysis. The analysis is generally inductive and multi-staged of the process of organizing, categorizing, synthesizing, interpreting and writing. Similar responses from the respondents are put in the same category.

\section{FINDINGS AND DISCUSSION}

\section{Findings}

The findings of this research were taken from the result of distributed questionnaires; the difficulties faced by the students in answering TOEFL test questions as the technique of data collection chosen previously. The data was prominent to explore the difficulties in answering TOEFL test questions. Based on the focus of this research, the data found were displayed and concentrated on the difficulties faced by the students in answering TOEFL test questions. As described in the research code of ethics, personal identities remain confidential, and the respondents stayed anonymous in this research.

Based on the data found from the questionnaire distributed before to the sample, it was found that most of the respondents found difficulties in answering the TOEFL Test and therefore unsuccessful of the tests. The difficulties categories were by Mahmud (2014). She found that the problems faced by the students in responding TOEFL tests questions were (1) fewer basic skills; (2) less practice; (3) less motivation and (4) Students' individual differences. Therefore, there were four variables of difficulties have been indicated in Mahmud's research (2014). Moreover, the researchers reveal the difficulties faced by the students in answering TOEFL test questions. Those problems then elaborated in accordance with the findings obtained from the questionnaire data, as follows:

\section{(1) Fewer Basic Skills}

The TOEFL questions the respondents have answered were the TOEFL prediction test questions for internally used only. The TOEFL scores obtained by the students were indicated as their basic skills in TOEFL. From 30 students taken as samples, there were 4 respondents or $13,33 \%$ from the sample got TOEFL score beneath 350 . Then, for the score range between 351 to 400 , there were 23 respondents or $76,67 \%$ been in this scope. The last range score found were in group of 401 to 450 with number of students 3 or $10 \%$. There were no respondents got score 451 above. 
This condition might be happened because they didn't put English as a habit. Furthermore, less awareness of the importance of English allow them to have no interest to practice it. It is assumed that, even though they have learned English for years, they still need adjustment towards the TOEFL test. It means that there should be a particular time allocated for tutoring TOEFL. This questionnaire, however, revealed that less listening skill is the dominant problem faced by the students. They said that it was hard to understand the pronunciation of the speaker, the accent, and grasping the meaning of the conversation in the listening section.

Another problem found from the questionnaire result was the students' low vocabulary mastery. They got difficulties finding the synonyms for the words in the Reading and knowing the meaning of the phrase in Listening section. Not less significant is the students' less English knowledge. It also proved to be the students' problem in answering the TOEFL test. Majority of them got difficulties the most in Listening, then followed by Structure and Written Expression and Reading Sections is put in the last as the least hard questions test they have answered.

\section{(2) Less Practice}

From the respondents' answer to the practice question, there were about $33,3 \%$ out of 30 students stated that they need more practice in the tryout. Although the implementation of the exercise has been carried out twice, it is still considered lacking by them. They want it done as frequently as possible. Meanwhile, as the matter of fact, generally English course in some popular English carry TOEFL simulation three times, one test was held before the students joining the course as the entry test to investigate the students' initial knowledge towards TOEFL test. The second test then is held in the midtime of the course. It is carried out to find out how far the students' comprehensibility in answering TOEFL test questions. The last is the finaltest. For the famous English courses and some Language center in campus, the final test given is ITP (Institutional Testing Program) which the certificate is not only as the report of their progress in the course but also as the file requirements to pursue their study abroad.

Before joining the test, previously the students enter the preparation class for about 10 hours. On that preparation class, the tips and tricks were given in answering the TOEFL question along with the examples of the questions and its explanations. So the total number of TOEFL test during the preparation class was two. However, this is considered less by the students. It is proven by the questionnaire's result where 30 students said that they need more practice during the preparation class.

Typically, the TOEFL preparation class has provided the students with tryout as frequently as possible. The respondents showed the need of practice should be done more than it used to 
be. Since most of the respondents were in the seventh semester in the English department and they are supposed to master English better than those who have no concern in studying English especially in the university level.

It is implied that most students rarely encountered the TOEFL test even for the TOEFL Preparation or simply said that the TOEFL test is something new for them. They got the TOEFL test only at the campus. It is sad since there is much access to learn TOEFL available outside the university.

This phenomenon impacted on their TOEFL test. Most of them got difficulties coping with the test duration. They are not accustomed to it and failed in time management during the test. Thus, the majority of them agreed to get themselves more practice in TOEFL.

\section{(3) Less Motivation}

Another problem faced by the students related to their difficulties in answering TOEFL test questions is motivation. It is found that their reasons for taking TOEFL test are only for one of the requirements of study completions fulfillment. It is proved by the number of students who stated their purpose as mentioned before is the highest one, there are 23 students from 30 samples (76.67\%). While five students (16.67\%) said that they join TOEFL test just for testing their ability in TOEFL, however, the rest reasons were to apply for a job and for pursuing education, where these two reasons were selected by one student (3.33\%) for each.

It is proved that motivation played an essential role in the success of the students in answering TOEFL. Since most students took TOEFL for merely fulfilling the requirement of the campus, they have less motivation to learn TOEFL outside the univesrity, such as joining a TOEFL Tryout or Preparation held by English courses or English institutions.

This condition also happened because of the students' financial problem. This circumstance influenced their motivation in joining the TOEFL Preparation or Tryout held by English courses or institutions. Taking TOEFL test or joining TOEFL Tryout is an expensive thing for them.

\section{(4) Students' Individual Differences}

The questionnaire given to the participants was to identify such personal data. They were assured that they stayed anonymous. Pseudonyms were used for all participants involved.

In many language test research analyses, personal background was considered to have small but significant effects on language tests such as native language, ethnicity, sex, ages and university status. Native language, for example, may lead to difficulties in answering other language questions since the interferences of the first language into the second language may 
occur (Zeidner, 1987). Thus, it is important to describe the participants' personal background anticipating that the difficulties may come from this aspect.

The participants in this research were 20 female students and ten male students. All of them were in the seventh-semester of English Department. All were between 21 and 27 years old. Thirteen students were Florinese; six students were Torajan, three students were Buginese, two students were Makassarese, two students were Mandarese, one student each was Selayar, Butonese, Bimanese, and Kajang. As much as 21 students stated that they had joined TOEFL test for three times, seven students asserted that they had joined TOEFL test for twice, and two students claimed they had joined TOEFL for four times. They had the score between 310 and 450.

From the questions about the influence of their local language, there were five students stated that their local language affects their ability in understanding English especially in answering the TOEFL test. Besides, 25 students reported that their local language did not affect them at all.

\section{Discussions}

TOEFL as a test tool to measure the proficiency of English is indeed more commonly used in various institutions in Indonesia, especially in universities, because this type of test is accessible to correct and relevant to universities that are oriented to the academic path. Since then, TOEFL test becomes a great challenge, not only for the students from faculties which has less concern to the English language but also from English department themselves. The great fear of failure must have been haunted them. The students from the English department should not have those fear, due to the time and the lesson even the language they use mostly English, but still, they struggle in dealing with this matter.

As mentioned before, the difficulties faced by the students that hindered them in TOEFL test achievement has been exposed. The contributing factors include fewer basic skills, less motivation, and less practice. Since English proficiency become the significant factors, the lack ability, especially in English, play the dominant role of the students' failure in TOEFL test performance. Considering that the students were from the English department, it is ironic that they have low mastery on English knowledge. Many factors caused the problem. Lack of training can be a factor but considering that these students are the seventh- semester students, researchers decided that this is not the main factor. The researchers then laid motivation as the major matter.

In teaching and learning activities, the role of motivation is very critical, because with the high motivation of the teacher and students the learning goals will be achieved optimally. 
Literally motivation as an impulse that arises in a person consciously or unconsciously, to carry out an act with a specific purpose. While psychologically, it means effort that can cause a person or group of people to move to do something because they want to achieve the goals they want or get the satisfaction with their actions. (KBBI, 2001: 756). It can be indicated that even though the students have spent for about three and a half years in campus studying English, if they do not trigger themselves to reach their goal, then their effort during that particular time is worthless.

According to Gage \& Berliner, 1984:412-441, there are two kinds of motivation; they are intrinsic and extrinsic motivation. Intrinsic motivation is what drives someone to do something without reinforcement and rewards from anyone. Moreover, extrinsic motivation is what motivates someone to do something based on the rewards. If one realizes his/herself has intrinsic motivation in them, the awards can cause the adverse influence/effect on their performances.

Regarding the statement above, it seems that intrinsic motivation acts the part of students succeeds in learning English. In term of TOEFL test, if there is no personal encouragement from within, even if the course is done for dozens of times it will not give meaningful change.

Brown (2000:160) stated that it is easy to assume that success in any task is due solely to the fact that someone is "motivated." Therefore, since the students' motivations placed as the main factor of the problem faced by the students in answering TOEFL, it is implied that the students were not motivated enough. As stated by Alizadeh (2016) in her journal that motivation is a crucial factor for explaining the success or failure of any strenuous activity and the success of task is due to the fact that someone is motivated. And due to the lack of motivation, some difficulties may happen for learners. Without the desire to learn, it is challenging for learners to gain effective learning. According to Huitt (2001), paying attention to the importance of language will help learners improve their motivation to learn even if they do not have enough intrinsic motivation. Very similar to Gardner (1985), motivation refers to the combination of attempt plus desire to obtain the objective of learning the language plus desirable attitudes towards learning the language. That is, motivation to learn a second language refers to the extent to which the individual works or tries to learn the language because of a desire to do so and the contentment experienced in this task. Effort alone does not indicate motivation. The motivated person spends energy towards the aim, but the person expending effort is not inevitably motivated.

As stated in the previous explanation, that motivation placed as the main factors in students' difficulties in answering TOEFL. Considering Alizadeh (2016) statement, that there 
are four types of motivation. The motivations are instrumental, integrative, intrinsic, and extrinsic motivation. The instrumental motivation refers to acquiring a language as a means for obtaining instrumental objectives such as furthering a career, reading technical materials, translation and so on. Hence, along with the result of this research that one of the reasons the students undertake the TOEFL because of study requirement of study completion fulfillment. Most of the respondents answered that the reason they take the TOEFL due to this reason.

The fact that the minimum score would be different on every campus and sometimes it is far from the international standard, the TOEFL issue is not taken seriously by the students. Since this issue occurs, they seem do not give all their effort to this matter however they still have a fear of failure. It indicated that they have the low feeling of competence and selfdetermination which is crucial.

Moreover, as many as ten students $(33,3 \%)$ out of thirty claimed that they need more practice in TOEFL. Meanwhile, the rest of it feel no unnecessity to carry out the TOEFL practice. It is pathetic since they scored low in their TOEFL but feel not urgent to achieve the better test result.

As for the students' individual differences such as the age of respondents, gender, ethnic identity, it seemed had no effects on the students' difficulties in answering the TOEFL test. This finding supported by a research result done by Mehrpour and Hosseini in their journal (2015). They tried to find out the effect of ethnic identity and motivation on the English language proficiency of Baluch language learners. In the investigation process, they used an abridged version of the General Ethnicity Questionnaire, a motivation questionnaire, and a sample of TOEFL test to collect the data from a group of Baluch learners of English. The collected data then subjected to multiple regression and correlational analysis. The result indicated that ethnic identity and motivation did not significantly influence the learner's language proficiency. Similarly, a non-significant correlation was identified between ethnic identity and motivation.

The students, however, they have fewer basic skills especially in English, but if they have high motivation in learning English, it will lead them to do more practice and automatically will achieve the best result in getting great skills. Besides, even though the student is a smart one but lazy, he/she will be beaten by those who are mediocre but diligent.

\section{E. CONCLUSION}

Based on the Findings and discussion of the data analysis, it is found that the difficulties faced by the students in answering TOEFL test on the seventh-semester from English 
department came from 3 main difficulties. The first was, fewer basic skills, that is related to the student's prior ability in answering TOEFL test questions, the second was less practice which focused on their frequency of practicing English in general and in TOEFL for specific and the third was lack of motivation that may come from external and internal of the students.

\section{REFERENCES}

Alizadeh, M. (2016). The Impact of Motivation on English Language Learning. International Journal of Research in English Education, Vol. 1, pp. 11-15, November 2016. Iran: ijreeonline Article. Accessed on September 12, 2018.

Brown, H, D. (2000). Principles of Language Learning and Teaching. New York: Longman

Clark, Nick. (2014). Testing English as A Foreign Language for University Admissions. Retrieved from http://wenr.wes.org/2014/10/testing-english-as-a-foreign-languagefor-university-admissions. On June 6, 2017 at 22.55.

Desheng, Chan \& Varghese. (2013). Testing and Evaluation of Language Skills. IOSR Journal of Research \& Method in Education (IOSR-JRME) e-ISSN: 2320-7388, p-ISSN: 2320737X Vol.1, Issue 2 (Mar.-Apr, 2013), PP 31-33.

Edustar English Center (2014) Beda ITP TOEFL dengan TOEFL Prediction Test. Retrieved from https://edustarjakarta.wordpress.com/2014/11/20/beda-itp-dan-predictiontoefl/ on August 17, 2018

Halim, Nurfitriyah. (2014). Cultural Bias in TOEFL Encountered by Native Indonesian Speakers. Renaissance Journal of English Education, Literature and Linguistics. Volime 1, No. 1,97-111.

Hardin, Kate. (2014). Common TOEFL Reading Difficulties. Retrieved from https://magoosh.com/toefl/2014/common-toefl-reading-difficulties/. On the June 5, 2017 at 20.50 .

Hussain, Shaffat, Tadesse, Sajid. (2015). Norm-Referenced and Criterion-Referenced Test in EFL Classroom. International Journal of Humanities and Social Science Invention ISSN (Online) Volume 4 Issue 10. PP. 24-30.

Mahmud, Murni. (2014). The EFL Students' Problems in Answering the Test of English as a Foreign Language (TOEFL). Theory and Practice in Language Studies, Vol. 4, No. 12, pp. 2581-2587, December 2014. Finland: Academy Publisher.

McGraw, Hill. (2009). ETS: The Official Guide to the TOEFL Test, Third Edition. United States of America: The McGraw-Hill Companies, Inc.

Mehrpour, Saeed and Hosseini, Seyyed. (2015). The Effect of Ethnic Identity and Motivation on English Language Proficiency of Baluch Language Learners. The International Research Journal "International Researchers" (Online) Volume No.4 Issue No.3. PP. $19-34$ 
Volume 4, Number 2, December 2018

Merriam Webster Online Dictionary. Accessed on July 31, 2018.

Pyle, M.A. and Mary E. M. (1986). Test of English as A Foreign Language, Preparation Guide. Singapore: John Wiley and Sons (SEA) Pte. Ltd.

Upshur, J. A. (1971). 'Productive communication testing: a progress report' in G. Perren and J.L.M. Trim (eds.): Applications in Linguistics. Cambridge University Press: 435 - 42

Huitt, W. (2005). Reasons for Lack of Motivation. Educational Psychology Interactive. Valdosta: Valdosta State University

Zeidner, M. (1987). 'A comparison of ethnic, sex and age biases in the predictive validity of English language aptitude tests: some Israeli data.' Language Testing 4,1: 55-71. 